\title{
Recent Constitutional Jurisprudence Concerning the European Union: Some Remarks on 2010 Judgments of the Polish Constitutional Court
}

\author{
Władysław Czapliński
}

(C) ERA 2011

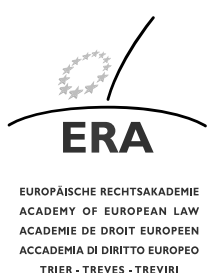

Abstract The author discusses two recent judgments of the Constitutional Court of Poland dealing with different aspects of the relationship between Polish constitutional law and EU law. The first decision dealt with the compatibility of the Lisbon Treaty with the Polish Constitution and the competence of the Polish institutions to ratify the Treaty; the second with the rather technical question of the Polish government's competence to implement EU regulations in Poland by adopting administrative regulations. In the first case the court held that ratification of the Treaty was in line with the Polish Constitution but, not unlike the German Constitutional Court, drew up a final line of competencies that could not constitutionally be transferred to the EU. In the second case, the Court concluded that, even if European Union regulations were directly binding and effective in the Member States, in exceptional cases these could legislate in order to ensure full effectiveness of Union law; however should this be done by administrative regulations adopted by the Polish government, the same requirements as to the precise designation of their framework and scope by the delegating act should apply as for the adoption of implementing regulations for Polish statutes.

Keywords Poland · EU · Constitution · Constitutional court · Lisbon Treaty · Regulations · Implementation

\section{Introduction}

Two judgments rendered by the Polish Constitutional Court in autumn 2010 require some comments. The nature of the decisions is totally different. The judgment of

Prof. W. Czapliński ( $\varangle)$

Instytut Nauk Prawnych PAN, Warszawa, Poland

e-mail: wczaplinski@uw.edu.pl 
24 November (Case K 32/09) concerned a matter that was fundamental from the perspective of Polish foreign policy and from the international perspective: the competence of Poland to ratify the Lisbon Treaty. On the other hand, another judgment of 13 October (Case Kp 01/09) dealt with a technical question of Polish constitutional law, namely the power of the government to enact legislative acts implementing European Union regulations. A dispute that arose among constitutional judges on the latter question shows, however, that the issue had a fundamental impact upon the consequences of membership of the European Union.

\section{Conformity of the Treaty of Lisbon with the Constitution}

Proceedings brought by a group of right-wing members of the Sejm (the lower chamber of the Polish parliament) concerned the impact of the Lisbon Treaty upon the sovereignty of the Republic of Poland. Doubts arose in connection with the power granted under the Treaty to the institutions of the European Union to enact legislative acts without the consent of the Polish government, and their effects on the domestic legal system. The applicants also denied the conformity with the Constitution of the principle of primacy of European law with respect to national legislation. The Court was asked to interpret - in the light of the new developments - Articles 8(1) and 90(1) of the Constitution. Both constitutional provisions had already been subject to interpretation in the judgment of the Court concerning conformity of the Treaty of accession of Poland to the European Union (Case 18/04, decision of 11 May 2005). In that judgment the Court declined to consider the Treaty contrary to the Constitution. It was clear that the 2005 decision was highly political, and the Court would not dare to reject the accession treaty, taking into account the results of the referendum on accession and the general support and sympathy of the Polish public opinion for integration with Europe. The 2010 judgment further developed ideas considered in the 2005 judgment, concentrating in particular on the meaning and content of state sovereignty. Issues at stake were the legislative mechanism within the European Union and its consequences for the domestic legal order, and the possible transfer of powers in favour of the European Union by way of a simplified procedure (known as a passerelle).

The applicants put in issue provisions of the Lisbon Treaty concerning law-making by the Council of the European Union alone or together with the European Parliament. Most laws can be adopted by qualified majority voting. It may therefore easily happen that a particular law can be adopted against the will of the Polish government. This implies that the Polish State can be bound by legal rules independently of the position of the government, which would allegedly be contrary to Article 90 of the Constitution. ${ }^{1}$ It was also possible, according to the applicants, that instruments adopted in accordance with the procedure in question might contain provisions contrary to the Constitution. In that situation, Article 8 of the Constitution (the supremacy clause) could be violated.

\footnotetext{
${ }^{1}$ This is the provision which entitles Poland to transfer the exercise of certain powers to an international organ or an international organisation, by concluding a specific international treaty. Special requirements must be met with respect to the entry into force of such an agreement.
} 
As far as concerns the passerelle clause, the applicants expressed the opinion that the transfer of powers introduced in this way would circumvent democratic control with respect to law-making, de facto depriving the parliament of its powers. This would be contrary to Article 90 paras. 2-3, read in conjunction with Articles 2 and 4 of the Constitution. The interests of the Republic of Poland would be formulated and represented exclusively by the Council of Ministers, and neither the Sejm nor the Senate (which is the upper chamber of the Polish parliament) would exercise control over that process.

Finally, the applicants also questioned the conformity of Declaration No. 17 which is attached to the Lisbon Treaty with Article 8 of the Constitution, proclaiming (as mentioned above) the principle of superiority of the Constitution over any other act in force within the Polish legal order. This principle of supremacy was confirmed by the Constitutional Court in the judgment concerning the Accession Treaty of 2005. Moreover, in the opinion of the applicants, the Declaration constitutes the first instrument proclaiming in clear and unequivocal terms, in an abstract way, the principle of priority of the application of European law as established in the jurisprudence of the European Court of Justice. The importance of the Declaration was not diminished, according to the applicants, by the fact that the Declaration - according to Article 51 of the Lisbon Treaty - did not acquire binding force and was not equivalent to the Treaty itself.

The applicants pointed out as well that the ratification of the Treaty of Lisbon should be accompanied by the adoption of a domestic legislative act (i.e., a statute) regulating different aspects of cooperation between different state agencies in the domain of European integration, and in particular between the parliament and government. We would like to emphasise, however, that the procedures of cooperation were established by the law of 11 March 2004 on the cooperation between the Council of Ministers and both Chambers of the Parliament, (which was subsequently replaced by a new act of 8 October 2010).

We do not intend to report here statements made in the proceeding by the competent state agencies, including the President of the Republic, the Speaker of the Sejm, the Minister of Foreign Affairs and the Minister of Justice/Attorney General. They all emphasised that the contentions of the applicants as to the alleged non-conformity of the Lisbon Treaty with the Constitution were groundless and should be rejected.

The decision of the Constitutional Court fully followed the opinions presented by the state agencies mentioned above. The judges stated at the very outset that the Lisbon Treaty had been ratified according to Article 90 of the Constitution. The provision provided a special procedure, requiring the cooperation of different institutions, including in particular the government, parliament, and president. None of them had had any doubt as to the conformity of the Treaty with the Constitution. According to the Constitutional Court, the said procedure should be interpreted as establishing a presumption of the conformity of the Lisbon Treaty with the Constitution. This presumption can be overcome only if it is established that when interpreted in a particular way, the Treaty may violate constitutional rules. On the other hand, the accession of Poland to the Union modified a perspective of the supremacy of the Constitution, but did not call it in question.

According to well-established case-law of the Constitutional Court, there was a clear connection between the sovereignty of the Republic and the supremacy of the 
Constitution with respect to the whole system of norms in force in the territory of Poland, notwithstanding their origin. In its previous jurisprudence the Court had emphasised that the Polish legal order was based upon a concept of monism. ${ }^{2}$ With all due respect, the present author is not convinced that there is a good ground in the Constitution for such a categorical statement. The monist concept paved the way towards a notion fashionable among Polish lawyers of "multicentrism" of the legal order in which a "cohabitation" of different sources of law can be observed.

The Court also emphasised that the notion of sovereignty undergoes a far-reaching evolution in the contemporary international legal order. It does not grant States an unlimited right to act in international relations free of any supervision, but it provides for limitations of freedom of action by the States, imposed by their international obligations. This freedom is in particular limited by the concept of human rights. The Court indicated a number of powers which are reserved for the exclusive power of States, including in particular exclusive jurisdiction with respect to their territories and nationals, foreign relations power including alliances, making peace and war, diplomatic relations, budgetary and financial policy, and membership in international organisations. We would like, however, to underline that the notion and content of sovereignty are subject to evolution. It is not possible to establish a category of powers constituting state sovereignty that are not universal and granted for ever. We could indicate for instance in this context transfers of powers concerning aliens (as have occurred within the context of the Schengen acquis).

The judges also recalled that the conclusion of an international agreement (including any treaty on the accession to an international organisation) cannot be treated as limiting state sovereignty, but on the contrary, constitutes an expression of sovereignty. This traditional (but still preserved) approach was proposed by the Permanent Court of International Justice in its first judgment in the Case of the "S.S. Wimbledon". 3 With respect to the transfer of powers to international organisations, including the European Union, the constitutional judges stated that this could not influence state sovereignty, and that in particular it could not diminish its scope, because this transfer was neither final nor irreversible. The Member States accepted only a joint exercise of certain State powers, remaining therefore "masters of the treaties". That position follows a model well established in German writing on European law. As regards the rule, it is correct, but we cannot forget that the European Court of Justice still retains an exclusive right to interpret European Union law. Although the Constitutional Court expressed a view that Kompetenz-Kompetenz remained with the Member States, we are not very convinced that the position is correct. It is unfortunate that Article I-6 of the Treaty Establishing a Constitution for Europe never entered into force - it contained a perfect regulation of the relationship between European Union law and domestic law of the Member States, even if it did not influence the sovereignty of the latter, providing as it did that "the Constitution and law adopted by the institutions of the Union in exercising competences conferred on it shall have

\footnotetext{
${ }^{2}$ Decision of 19 December 2006, case P 37/05, para III.3.

${ }^{3}$ http://www.worldcourts.com/pcij/eng/decisions/1923.08.17_wimbledon.htm. Citation: S.S. Wimbledon (U.K. v. Japan), 1923 P.C.I.J. (ser. A) No. 1.
} 
primacy over the law of the Member States." Under the current version of the European treaties, the dispute concerning supremacy (European Union law) remains unresolved, what is not bad taking into account the strength of euroscepticals in European Union Member States. According to the Constitutional Court, the primacy of the constitutions remains a guarantee of state sovereignty, in particular as - in the case of Poland - any change of the Constitution in the way of international treaties would be unlawful and invalid.

In order to confirm the supremacy of the Constitution, the Court formulated a list of powers that could not be transferred to the Union. ${ }^{4}$ This catalogue encompassed the principle of the sovereignty of the nation (Article 4), the integrity of the territory, fundamental rights and freedoms of the citizens (Article 5), as well as guarantees of human dignity and constitutional rights, principles of democracy, the rule of law, social justice, subsidiarity, and the constitution-making power vested in the Nation. The Court had no doubt that these axiological principles of the Polish Constitution corresponded with the values of the Union. The Constitutional Court also stated that the principle of conferred powers as a basis of action of the European Union as formulated in Article 3 para. 6 of the Treaty on the European Union, expressed the same idea of state sovereignty, as powers not assigned to the Union remained a domain of the Member States. The states were fully responsible for all measures aimed at preserving their territorial integrity and internal security.

On the other hand, the Court emphasised that Article 90 of the Constitution (constituting the basis of the transfer of powers to the European Union) still remained relevant. We agree with this submission, as although the provision in question was obviously introduced into the Constitution with a view to enabling Poland to accede to the European Union, its relevance is not limited to European Union membership. The reference to Article 90 was considered e.g., as a basis for ratification by Poland of the Rome Statute of the International Criminal Court. The idea was however abandoned.

Another important issue proposed by the Court was that the scope of the powers transferred to the Union should be more specific and cannot be understood or interpreted extensively. In particular the powers transferred cannot modify the Constitution.

One may conclude on the point that the Constitutional Court of Poland in its 2010 judgment on the Treaty of Lisbon developed its previous jurisprudence, emphasising once more the fundamental importance of the Constitution as a visible source and emanation of state sovereignty. From the perspective of this author, the decision is too conservative, even if it generally expresses a positive attitude towards European integration.

\section{The Role of European Legislation in the Domestic Order - the Power of the Government to Enact Regulations Based upon European Union Acts}

Although it has been stated above that the issue under consideration was a rather technical one, it gave rise to significant differences among the constitutional judges

\footnotetext{
${ }^{4}$ In fact, the Court continues the line proposed by the Maastricht judgment of the German Federal Constitutional Court.
} 
as is shown by the dissenting opinions formulated by four judges belonging to the "euro-enthusiastic" fraction within the Court.

In January 2009, the late President Kaczyński asked the Court to check the conformity of Article 23 of the law on the organisation of the fisheries market of 2008. The provision establishes an obligation to sell certain sorts of fish which are subject to a special regime exclusively at so-called centres of first sale, defined by a minister competent for fishery matters. The detailed procedure is required to be specified by a governmental act. According to the President, such a delegation violated the constitutional principle of the freedom of economic activities and could lead to monopolies in the field in question. The proposed regulation was of a framework nature, and therefore the President considered it contrary to constitutional requirements. The government had decided to regulate this issue by an ordonnance (administrative regulation).

However, the European Union Regulation on establishing a control system applicable to the common fisheries policy (No. 2847/93 of 12 October 1993) was not considered by the Court to be a sufficient basis for the governmental ordonnance.

According to the constitutional rules in force (which are important as a model for review), administrative regulations can be enacted by the government only in order to implement parliamentary statutes and only in the framework and scope precisely designated by statute (Article 92 of the 1997 Constitution). As the fisheries policy belongs to the exclusive competence of the European Union, according to a constant and coherent jurisprudence of the European Court of Justice Member States are precluded from law-making in that domain. In fact, there is a certain conflict between the Constitution and European Union law as to whether European Union regulations should be implemented by statutes (meeting the criteria of precise, clear, and exhaustive regulation), or whether they could possibly be implemented by governmental ordonnances based directly upon European Union instruments.

Parties to the proceedings supported the existing legislation. The Speaker of the Sejm (on behalf of parliament) argued in favour of the existing provisions, stating in particular that respective provisions of the Constitution did not exclude establishing certain restrictions upon the freedom of economic activity by the Government, as that field was neither reserved to the Constitution nor to parliamentary powers. The freedom of regulation by the government is however limited by European Union acts. The Speaker's position seems significant, as the issue is strictly connected with prerogatives of the parliament. A similar position was taken by the Attorney General who emphasised that the powers conferred upon the government by the law were not mandatory, so that the competent Minister was not obliged to legislate. If he did, however, his action had to be kept within the limits established by the common fisheries policy.

The Court in its judgment in Case Kp 01/09 emphasised that it had a right to check the conformity of the Polish regulation with the Constitution, but it did not consider the position of respective European Union acts in this respect. It analysed for the most part (in a very detailed way) the main elements of the common fisheries policy, indicating in particular the exclusive powers of the Union in that field. Furthermore, even if European Union regulations were directly binding and effective in the domestic legal orders of Member States, in exceptional cases states could legislate in order 
to ensure full effectiveness of Union law. This was so in the case of the common fisheries policy. According to regulation 2371/2002, the states were under an obligation to exercise full and effective control on the implementation of the fisheries policy. Regulation 2837/93 quoted above was one of the instruments covering this field. The new Regulation 1224/2009 of 20 November 2009 modified the existing legislation in order to make European Union law more effective. It was meant to introduce a unified and coherent system of control, based on new information technologies including an electronic system of verification of fishing activities and a satellite system of monitoring of fishing vessels. The Court remarked that the Regulation constituted an important element of control. This control was justified by the requirement to protect the natural environment and met the criteria of general public interest as a premise of imposing restrictions upon the freedom of economic activity. However, according to the majority of the constitutional judges, these restrictions should be established by law and not by a "blanket" delegation to be exercised by the Government. The Court emphasised in its conclusion that the entry into force of Regulation 1224/2009 could possibly modify and amend the scope of application of Polish domestic rules concerning the fisheries policy, but this question was not examined by the Court.

As stated above, four judges dissented, rejecting the position of the Court on the point of the relationship between European Union law and domestic law. The present author fully shares their stance. The argument on requirements of statutory regulation would be correct if the fisheries policy was regulated exclusively by Polish domestic legislation. As the European Union regulations are directly effective in the Polish legal order and are superior to domestic acts, prevailing in cases of conflict (according to Article 91 para. 3 of the Polish Constitution), the freedom of action of the Government is limited by European law. Domestic acts concerning fisheries are aimed at implementing European Union law and not domestic statutes. The argument on imprecise delegation formulated by the Court must therefore be rejected. Moreover, the Constitution, just like the whole domestic order of the Member States, should be interpreted in a European Union-friendly way according to the principle of loyal cooperation. This was not taken into account by the majority of the Court.

\section{Conclusions}

President Komorowski recently decided to bring draft amendments to the Constitution before parliament. The idea underlying this initiative has been that nearly seven years after the accession of Poland to the European Union, the time has come to regulate in a detailed way all of the issues connected with membership - including providing a final resolution of matters of dispute such as state sovereignty, the axiology of the Union, and the relationship between European law (secondary legislation) and Polish domestic law. The presidential proposal deserves support, as it was not possible to include specific and detailed provisions relating to the European Union in the Constitution which was adopted in the pre-accession period; moreover, the experiences of membership has permitted the formulation of conclusions which will be reflected in the constitutional text. It is unclear whether the amendments will find sufficient support among parliamentarians, and if so, how long it will take to pass 
the legislation. It is to be hoped that the final result will be satisfactory and that it will constitute a legal basis reflecting the importance of membership to the European Union for Poland and her citizens.

We would like also to quote - at the end of the present chapter - an important statement by the Constitutional Court, summing up the jurisprudence of the constitutional courts of other Member States, including, in particular, the courts of Germany, France, Austria, the Czech Republic and Latvia. All decisions of these courts mirrored, according to the Polish Court, the importance of state sovereignty in the current stage of European integration. The constitutional jurisprudence also stressed the important role of constitutional tribunals in preserving the constitutional identity of the Member States - but also in establishing the limits of Treaty identity of the Union. 